\title{
Comparison of Blood Strips, Milk Strips and Automated Milk Measurement of Beta-Hydroxybutyrate in Periparturient Dairy Cattle and Resultant Diagnoses of Ketosis
}

\section{David J Wilson*and Gregory M Goodell}

Department of Animal, Dairy, and Veterinary Sciences, Utah State University, Utah Veterinary Diagnostic Laboratory, 950 East 1400 North, Logan, UT 84341, USA

\begin{abstract}
Beta-hydroxybutyrate (BHB) is a ketone measured in blood or milk of dairy cattle after calving for detection of ketosis. Blood test strips, milk test strips, DHIA milk meter collected samples and hand stripped milk samples, both latter milks tested with Fossomatic analyzer, were compared for BHB measurement. Blood and milk samples were collected on the same day from 446 Holstein cows between 1-14 DIM in 5 herds for BHB testing as described above. Most test methods had continuous results but one (milk strip) had categorical results (ranges of $\mu \mathrm{mol} B \mathrm{BB}$ /L); analysis compared whether or not each pair of BHB tests categorized the same cows as ketotic or non-ketotic (concordant, C) or disagreed on their status (discordant, D). Blood strips detected 53 ketotic (K) $(\geq 1200 \mu \mathrm{mol}$ $\mathrm{BHB} / \mathrm{L}), 393$ non-ketotic (N); milk strips detected $34 \mathrm{~K}$ ( $\geq 200 \mu \mathrm{mol} \mathrm{BHB} / \mathrm{L}$ category on strip), $408 \mathrm{~N}$; milk meter Foss detected $29 \mathrm{~K}(\geq 200 \mu \mathrm{mol} / \mathrm{L}), 399 \mathrm{~N}$; stripped milk Foss detected $41 \mathrm{~K}(\geq 200 \mu \mathrm{mol} / \mathrm{L}), 297 \mathrm{~N}$. Test comparisons: blood/milk strips $15 \mathrm{~K} / \mathrm{K}, 371 \mathrm{~N} / \mathrm{N}(87 \% \mathrm{C}), 37 \mathrm{~K} / \mathrm{N}, 19 \mathrm{~N} / \mathrm{K}(13 \% \mathrm{D})$; blood/milk meter Foss $10 \mathrm{~K} / \mathrm{K}, 357 \mathrm{~N} / \mathrm{N}(86 \%$ C), $42 \mathrm{~K} / \mathrm{N}, 19 \mathrm{~N} / \mathrm{K}(14 \%$ D); blood/stripped milk Foss $10 \mathrm{~K} / \mathrm{K}, 266 \mathrm{~N} / \mathrm{N}(82 \% \mathrm{C}), 31 \mathrm{~K} / \mathrm{N}, 31 \mathrm{~N} / \mathrm{K}$ (18\% D); milk strips/ milk meter Foss 7 K/K, $372 \mathrm{~N} / \mathrm{N}(89 \% \mathrm{C}), 27 \mathrm{~K} / \mathrm{N}, 22 \mathrm{~N} / \mathrm{K}(11 \% \mathrm{D})$; milk strips/stripped milk Foss $16 \mathrm{~K} / \mathrm{K}, 287 \mathrm{~N} / \mathrm{N}$ $(90 \%$ C), $10 \mathrm{~K} / \mathrm{N}, 25 \mathrm{~N} / \mathrm{K}(10 \% \mathrm{D})$; milk meter Foss/stripped milk Foss $5 \mathrm{~K} / \mathrm{K}, 272 \mathrm{~N} / \mathrm{N}(84 \% \mathrm{C}), 20 \mathrm{~K} / \mathrm{N}, 33 \mathrm{~N} / \mathrm{K}(16 \%$ D). Results show that the BHB test methods agreed well for most non-ketotic cows, but tests did not agree well on classification of ketotic cows. Calibration improvements are a priority for improved Fossomatic testing of BHB in milk.
\end{abstract}

\section{Keywords: BHB; Ketosis; Milk; Cows}

\section{Introduction}

Measurement of beta-hydroxybutyrate (BHB) in blood is a common test for detection of subclinical ketosis and negative energy balance in dairy cattle following calving. Laboratory methods for mechanical measurement of BHB in ruminant serum, plasma or blood are validated and widely accepted [1]. Concentration of BHB $>1200 \mu \mathrm{mol} / \mathrm{L}$ is used as the defining threshold of subclinical ketosis, and has been associated with increased risk of left displaced abomasum (LDA) and metritis in recently calved cows [2-4]. The threshold of $>1200 \mu \mathrm{mol} / \mathrm{L}$ BHB has also been used as an indication to treat dairy cows with oral propylene glycol daily until their blood concentration of BHB decreases below that level [4]. Prevalence of ketosis has been estimated between $12 \%$ and $47 \%$ of dairy cows, most common in the first weeks after calving $[2,3]$. Ketosis and negative energy balance may also result in decreased immune function of cows in early lactation [5]

More recently, blood measurement of BHB in cattle has utilized the Precision XTRA'1 drop blood meter (Abbott Labs, Abbott Park, IL), originally developed for human medicine. One drop of blood is placed onto a test strip and inserted into the meter; results are displayed in 10 sec. Results are reported to have excellent agreement with established laboratory measurements $\left(\mathrm{R}^{2}=0.987\right)$ and the test is used exactly as labeled for human blood testing of BHB [6].

A milk ketone semi quantitative colorimetric dipstick test has been increasingly adopted in the U.S., the Keto-Test (Elanco, Greenfield, IN). When this test was still known as the Ketolac test, it was found useful and accurate as a measure of BHB in milk, and as a diagnostic test for ketosis and negative energy balance in a study of 469 dairy cows in 21 herds [7]. When milk is placed on the Keto-Test strip, the gradations of color change correspond to ranges of BHBA concentration. However, the relationship between the ranges of $\mathrm{BHB}$ to the continuous quantitative values of the blood test strip, including comparison of the tests' classifications of cows as ketotic or non-ketotic, have not been reported.

The Fossomatic (Foss, Eden Prairie, MN) milk analyzer machine is widely used for high throughput low cost testing of milk samples throughout the developed world [8]. Milk from approximately half of the dairy cattle in the U.S. is tested monthly by the Dairy Herd Improvement Association (DHIA) for other milk components and parameters, much of it using Fossomatic analysis. However, there is no commercial method available for BHB testing of milk samples using the Fossomatic in the US. There are no reported studies of agreement or disagreement in classification of cows as ketotic or non-ketotic in comparison with other BHB test methods.

The objective of this study was comparison of four test methods for BHB determination of dairy cattle: blood test strips, milk test strips, DHIA milk meter collected samples and hand stripped milk samples, both of the latter milk samples tested with an automated high throughput Fossomatic milk analyzer, for BHB measurement. This included comparison of each pair of test methods for classification of the same population of recently calved cows into the categories of ketotic or non-ketotic.

*Corresponding author: David J Wilson, Department of Animal, Dairy, and Veterinary Sciences, Utah State University, Utah Veterinary Diagnostic Laboratory, 950 East 1400 North, Logan, UT 84341, USA, Tel: 435-760-3731; Fax: 435-7972805; E-mail: David.Wilson@usu.edu

Received June 14, 2013; Accepted June 28, 2013; Published June 30, 2013

Citation: Wilson DJ, Goodell GM (2013) Comparison of Blood Strips, Milk Strips and Automated Milk Measurement of Beta-Hydroxybutyrate in Periparturien Dairy Cattle and Resultant Diagnoses of Ketosis. J Veterinar Sci Technol 4: 136. doi:10.4172/2157-7579.1000136

Copyright: @ 2013 Wilson DJ, et al. This is an open-access article distributed unde the terms of the Creative Commons Attribution License, which permits unrestricted use, distribution, and reproduction in any medium, provided the original author and source are credited. 
Citation: Wilson DJ, Goodell GM (2013) Comparison of Blood Strips, Milk Strips and Automated Milk Measurement of Beta-Hydroxybutyrate in Periparturient Dairy Cattle and Resultant Diagnoses of Ketosis. J Veterinar Sci Technol 4: 136. doi:10.4172/2157-7579.1000136

\section{Materials and Methods}

\section{Study herds}

Five commercial Holstein dairy farms in Colorado participated in the study, with numbers of lactating cows and $305 \mathrm{~d}$ mean milk production as follows: Herd A, 5,500 lactating cows, 24,984 lb (11,343 $\mathrm{kg}) 305 \mathrm{~d}$ mean milk production; Herd B, 3,440 cows, 20,421 lb (9,271 $\mathrm{kg})$; Herd C, 3,650 cows, 18,156 lb (8,243 kg); Herd D, 1,828 cows, $22,171 \mathrm{lb}(10,066 \mathrm{~kg})$; Herd E, 2,680 cows, 21,350 lb (9,693 kg).

\section{Blood and milk sample collection}

Preliminary study found few cows detected as ketotic after 14 days in milk (DIM). Therefore Holstein cows from 1-14 DIM in the 5 herds were blood and milk sampled for BHB testing. Cows within each herd were all sampled on the same day. Cows were blood sampled from the coccygeal (tail) vein in lock-up stalls and milk samples were collected during the next milking.

\section{Blood and milk beta-hydroxybutyrate test methods}

Ketone blood test strips were inserted into the Precision XTRA 1 drop blood meter, as is required, before blood was applied. After collection from the coccygeal vein, one small drop of blood was placed onto the test strip already positioned in the blood meter, and after 10 $\mathrm{sec}$, results were displayed as $\mathrm{BHB}$ concentration in $\mathrm{mmol} / \mathrm{L}$ [6]. Results were multiplied by 1000 to convert them to $\mu \mathrm{mol} \mathrm{BHB} / \mathrm{L}$, and recorded for each cow.

In the milking parlor, milk was collected and placed on the Keto-Test strip, with gradations of color change indicating $\mathrm{BHB}$ concentrations of $0,50,100,200,500$, or $1000 \mu \mathrm{mol} / \mathrm{L}$ [7]. Milk was also proportionally collected into sample vials during milking using DHIA milk meters, and milk was also hand stripped into additional sample vials. Both of the latter types of milk samples were transported to the laboratory of The Dairy Authority in Greeley, CO for testing using the Fossomatic milk analyzer, with BHB concentrations measured in $\mu \mathrm{mol} / \mathrm{L}$. All milk $\mathrm{BHB}$ results were recorded for each cow.

\section{Statistical analysis}

Most test methods produced continuous results but one (milk test strip) produced categorical results $(0,50,100,200,500,1000 \mu \mathrm{mol}$ $\mathrm{BHB} / \mathrm{L})$. Nevertheless, all of these BHB tests are used with a threshold to classify cows categorically as ketotic or non-ketotic. Therefore the analyses compared whether or not each pair of BHB tests categorized the same cows as ketotic or non-ketotic (concordant) or disagreed on their ketosis status (discordant). Test of significance for agreement between each pair of test methods on the same cows was by kappa value.

\section{Results}

Holstein cows $(\mathrm{n}=446)$ from 1-14 DIM were sampled at one visit to each of the 5 study herds as follows: Herd A, 115 cows; Herd B, 80 cows; Herd C, 157 cows; Herd D, 27 cows; Herd E, 67 cows. Four cows that had been blood sampled were not found in the milking parlor during the next milking time ( $\mathrm{n}=442$ for milk test strips), 14 additional cows' milk samples collected by milk meter were of insufficient volume for BHB testing to be done ( $\mathrm{n}=428$ for milk meter Foss), and no hand stripped milk samples were collected from the 80 cows from Herd B and a total of 28 other cows ( $\mathrm{n}=338$ for milk stripped Foss).

Cows were classified by each BHB test method as follows: blood test strips 53 ketotic $(\mathrm{K})(\geq 1200 \mu \mathrm{mol} \mathrm{BHB} / \mathrm{L})(12 \%), 393$ non-ketotic $(\mathrm{N})$ (88\%); milk test strips $34 \mathrm{~K}$ ( $\geq 200 \mu \mathrm{mol} \mathrm{BHB} / \mathrm{L}$ category on strip) (8\%), $408 \mathrm{~N}$ (92\%); milk meter Foss $29 \mathrm{~K}(\geq 200 \mu \mathrm{mol} / \mathrm{L})(7 \%), 399 \mathrm{~N}(93 \%)$; stripped milk Foss $41 \mathrm{~K}$ ( $\geq 200 \mu \mathrm{mol} / \mathrm{L})(12 \%), 297 \mathrm{~N}(88 \%)$.

Test comparisons, showing number of cows in each category: blood/milk strips $15 \mathrm{~K} / \mathrm{K}, 371 \mathrm{~N} / \mathrm{N}$ (87\% concordant, C), $37 \mathrm{~K} / \mathrm{N}, 19$ N/K (13\% discordant, D); blood/milk meter Foss $10 \mathrm{~K} / \mathrm{K}, 357 \mathrm{~N} / \mathrm{N}$ (86\% C), $42 \mathrm{~K} / \mathrm{N}, 19 \mathrm{~N} / \mathrm{K}(14 \% \mathrm{D})$; blood/stripped milk Foss $10 \mathrm{~K} / \mathrm{K}$ $266 \mathrm{~N} / \mathrm{N}$ (82\% C), $31 \mathrm{~K} / \mathrm{N}, 31 \mathrm{~N} / \mathrm{K}$ (18\% D); milk strips/milk meter Foss $7 \mathrm{~K} / \mathrm{K}, 372 \mathrm{~N} / \mathrm{N}(89 \% \mathrm{C}), 27 \mathrm{~K} / \mathrm{N}, 22 \mathrm{~N} / \mathrm{K}$ (11\% D); milk strips/ stripped milk Foss $16 \mathrm{~K} / \mathrm{K}, 287 \mathrm{~N} / \mathrm{N}(90 \% \mathrm{C}), 10 \mathrm{~K} / \mathrm{N}, 25 \mathrm{~N} / \mathrm{K}(10 \% \mathrm{D})$; milk meter Foss/stripped milk Foss 5 K/K, 272 N/N (84\% C), 20 K/N, $33 \mathrm{~N} / \mathrm{K}(16 \% \mathrm{D})$.

Kappa evaluation of test agreement was: blood/milk strips "fair" ( $\mathrm{k}=0.28) ;$ blood/milk meter Foss "poor" ( $\mathrm{k}=0.18)$; blood/stripped milk Foss "poor" ( $\mathrm{k}=0.14)$; milk strips/milk meter Foss "poor" ( $\mathrm{k}=0.08)$; milk strips/stripped milk Foss "moderate" ( $\mathrm{k}=0.42)$; milk meter Foss/ stripped milk Foss "poor" ( $\mathrm{k}=0.07)$.

Sensitivity (Se) and specificity (Sp) depend upon "gold standard" chosen. If blood strips are used as the gold standard for "true" ketosis status, milk strips $\mathrm{Se}=29 \%, \mathrm{Sp}=95 \%$; milk meter Foss $\mathrm{Se}=19 \%, \mathrm{Sp}=95 \%$; stripped milk Foss $\mathrm{Se}=24 \%, \mathrm{Sp}=90 \%$. These and other Se and Sp values when each of the tests is used as the gold standard are reported in Table 1. Sensitivity, the probability of one test to detect "true" (according to the gold standard test) ketotic cows, was low, ranging between $13 \%$ and $44 \%$, while specificity, the probability of one test to detect "true" ketosisnegative cows, was relatively high, usually above $90 \%$ (Table 1 ). This reflects the fact that while all of the tests were in comparative agreement (C) regarding cows without ketosis, they disagreed (D) regarding many cows that one BHB test or the other detected as ketotic.

When considering only those cows detected by one test or the other in each pair of BHB tests as ketotic, the number (\%) of ketotic cows that tests were $\mathrm{C}$ for, and the number (\%) of ketotic cows that the tests were $\mathrm{D}$ for is as follows: blood/milk strips $15 \mathrm{~K} / \mathrm{K}(\mathrm{C}, 21 \%) 37 \mathrm{~K} / \mathrm{N}+19 \mathrm{~N} /$ $\mathrm{K}=56 \mathrm{D}$ (79\%); blood/milk meter Foss $10 \mathrm{~K} / \mathrm{K}(\mathrm{C}, 14 \%), 42 \mathrm{~K} / \mathrm{N}+19 \mathrm{~N} /$ $\mathrm{K}=61 \mathrm{D}(86 \%) ;$ blood/stripped milk Foss $10 \mathrm{~K} / \mathrm{K}(\mathrm{C}, 14 \%), 31 \mathrm{~K} / \mathrm{N}+31$ $\mathrm{N} / \mathrm{K}=62 \mathrm{D}$ (86\%); milk strips/milk meter Foss $7 \mathrm{~K} / \mathrm{K}$ (C, 13\%), $27 \mathrm{~K} / \mathrm{N}$

\begin{tabular}{|c|c|c|c|c|}
\hline \multirow[t]{2}{*}{ "Gold standard" } & \multicolumn{4}{|c|}{ Sensitivity and specificity of BHB test when compared with each gold standard } \\
\hline & Blood strips* & Milk strips $†$ & Milk meter Foss $\ddagger$ & Stripped milk Foss§ \\
\hline Blood strips & N/A & Se $29 \%$, Sp $95 \%$ & Se $19 \%$, Sp $95 \%$ & Se $24 \%$, Sp $90 \%$ \\
\hline Milk strips & Se $44 \%$, Sp $91 \%$ & N/A & Se $21 \%$, Sp $94 \%$ & Se $62 \%$, Sp $92 \%$ \\
\hline Milk meter Foss & Se $34 \%$, Sp $89 \%$ & Se $24 \%$, Sp $93 \%$ & $\mathrm{~N} / \mathrm{A}$ & Se $20 \%$, Sp $89 \%$ \\
\hline Stripped milk Foss & Se $24 \%$, Sp $90 \%$ & Se $39 \%$, Sp $97 \%$ & Se $13 \%$, Sp $93 \%$ & N/A \\
\hline
\end{tabular}

* Blood test strips tested in Precision XTRA ${ }^{\circledR}$ meter

† Keto-Test ${ }^{\circledR}$ milk test strips

$\ddagger$ DHIA milk meter collected samples tested with Fossomatic ${ }^{\circledR}$ milk analyzer

$\S$ Hand stripped milk samples tested with Fossomatic ${ }^{\circledR}$ milk analyzer

Table 1: Sensitivity and specificity of beta-hydroxybutyrate test methods when each test is used as the "gold standard" in comparison with the others 
Citation: Wilson DJ, Goodell GM (2013) Comparison of Blood Strips, Milk Strips and Automated Milk Measurement of Beta-Hydroxybutyrate in Periparturient Dairy Cattle and Resultant Diagnoses of Ketosis. J Veterinar Sci Technol 4: 136. doi:10.4172/2157-7579.1000136

Page 3 of 3

$+22 \mathrm{~N} / \mathrm{K}=49 \mathrm{D}(87 \%) ;$ milk strips/stripped milk Foss $16 \mathrm{~K} / \mathrm{K}$ (C, 31\%), $10 \mathrm{~K} / \mathrm{N}+25 \mathrm{~N} / \mathrm{K}=35 \mathrm{D}(69 \%) ;$ milk meter Foss/stripped milk Foss 5 $\mathrm{K} / \mathrm{K}(\mathrm{C}, 9 \%), 20 \mathrm{~K} / \mathrm{N}+33 \mathrm{~N} / \mathrm{K}=53 \mathrm{D}(91 \%)$.

\section{Discussion}

None of the $4 \mathrm{BHB}$ test methods agreed well regarding classification of cows as ketotic; the tests had higher agreement regarding which cows were non-ketotic based on BHB concentration. While the percentage of cows detected as ketotic (12\%) was the same for blood BHB test strips and stripped milk samples tested for BHB using the Fossomatic, over $90 \%$ of the cows detected as ketotic by blood test strips and stripped milk Foss were different cows. The other milk BHB tests detected fewer ketotic cows, approximately $8 \%$. Blood is considered a more ideal substrate than milk for accurate detection of ketosis in dairy cows, and milk and blood BHB measurements have been reported previously to be poorly related [9].

The prevalence of ketosis among cows 1-14 DIM in the study herds was $12 \%$ according to the blood test strips. Some studies have found ketosis at higher levels in dairy herds, but ketosis prevalence of $9 \%$ and $12 \%$, similar to the study reported here, has been reported previously in a total of 100 dairy herds $[7,9]$.

The milk test strips and the stripped milk Foss method had the closest agreement among any two of the BHB tests for ketosis. While this suggests that there may be potential for replacing the cow-side milk BHB test strips with more convenient, rapid and inexpensive testing of milk samples through the Foss, this potential will probably only be fully realized if DHIA milk meter collected samples, which did not perform as well in this study, can be used to test cows for ketosis instead of hand stripped samples.

The authors are convinced from handling the BHB test using the Fossomatic that calibration of the machine for BHB analysis can be and needs to be improved. If this is successfully accomplished, further investigation of the utility of BHB testing using milk meter collected samples will be warranted. The potential for reducing cost and increasing convenience and throughput in testing cows for ketosis using milk samples, especially samples collected at DHIA visits, is great enough to make continued investigation a priority for the dairy industry.

\section{Acknowledgements}

This research was made possible through financial support from a cooperative extension grant at Utah State University. We would also like to thank the owners and staff of the cooperating dairy farms and the staff at the Dairy Authority.

\section{References}

1. Knox DP, Jones DG (1984) An automated micro-method for the enzymatic determination of D-B-hydroxybutyrate in ruminant plasma. Vet Res Commun 8: 103-115.

2. Duffield TF, Lissemore KD, McBride BW, Leslie K (2009) Impact of hyperketonemia in early lactation dairy cows on health and production. J Dairy Sci 92: 571-580

3. Gonzalez FD, Muino R, Pereira V, Campos R, Benedito JL (2011) Relationship among blood indicators of lipomobilization and hepatic function during early lactation in high-yielding dairy cows. J Vet Sci 12: 251-255.

4. McArt JA, Nydam DV, Ospina PA, Oetzel GR (2011) A field trial on the effect of propylene glycol on milk yield and resolution of ketosis in fresh cows diagnosed with subclinical ketosis. J Dairy Sci 94: 6011-6020.

5. Franklin ST, Young JW, Nonnecke BJ (1991) Effects of ketones, acetate butyrate, and glucose on bovine lymphocyte proliferation. J Dairy Sci 74: 25072514

6. Oetzel G, McGuirk S (2009) Fact sheet - cowside BHBA testing with a handheld "ketometer". University of Wisconsin Fact Sheet. 4: 1-4.

7. Geishauser T, Leslie K, Tenhag J, Bashiri A (2000) Evaluation of eight cow-side ketone tests in milk for detection of subclinical ketosis in dairy cows. J Dairy Sci 83: 296-299.

8. McKenna D (1994) Accuracy and precision of Fossomatic 250/300/360 series of somatic cell counters compared to Fossomatic 215: collaborative study. J AOAC Int 77: 932-938.

9. Iwersen M, Falkenberg U, Voigtsberger R, Forderung D, Heuwieser W (2009) Evaluation of an electronic cowside test to detect subclinical ketosis in dairy cows. J Dairy Sci 92: 2618-2624. 